\title{
Changes in the geometry and strength of the Atlantic meridional overturning circulation during the last glacial (20-50 ka)
}

\author{
Pierre Burckel $^{1,2}$, Claire Waelbroeck ${ }^{1}$, Yiming Luo ${ }^{3}$, Didier M. Roche ${ }^{1,4}$, Sylvain Pichat ${ }^{5}$, Samuel L. Jaccard ${ }^{6}$, \\ Jeanne Gherardi ${ }^{1}$, Aline Govin ${ }^{1}$, Jörg Lippold ${ }^{6}$, and François Thil ${ }^{1}$ \\ ${ }^{1}$ Laboratoire des Sciences du Climat et de l'Environnement, LSCE/IPSL, CEA-CNRS-UVSQ, Université Paris-Saclay, \\ 91191 Gif-sur-Yvette, France \\ ${ }^{2}$ Institut de Physique du Globe de Paris, Université Sorbonne Paris Cité, 75238 Paris, France \\ ${ }^{3}$ Dalhousie University, Department of Oceanography, 1355 Oxford Street, P.O. BOX 15000, Halifax, NS B3H 4J1, Canada \\ ${ }^{4}$ Department of Earth Sciences, Earth and Climate Cluster, Faculty of Earth and Life Sciences, Vrije Universiteit Amsterdam, \\ Amsterdam, the Netherlands \\ ${ }^{5}$ Laboratoire de Géologie de Lyon (LGL-TPE), Ecole Normale Supérieure de Lyon, 46 allée d'Italie, 69007 Lyon, France \\ ${ }^{6}$ Institute of Geological Sciences and Oeschger Centre for Climate Change Research, University of Bern, Baltzerstr. 1 \& 3 , \\ 3012, Bern, Switzerland
}

Correspondence to: Pierre Burckel (burckel@ipgp.fr)

Received: 26 February 2016 - Published in Clim. Past Discuss.: 11 March 2016

Revised: 11 September 2016 - Accepted: 29 September 2016 - Published: 8 November 2016

\begin{abstract}
We reconstruct the geometry and strength of the Atlantic meridional overturning circulation during the Heinrich stadial 2 and three Greenland interstadials of the 20$50 \mathrm{ka}$ period based on the comparison of new and published sedimentary ${ }^{231} \mathrm{~Pa} /{ }^{230} \mathrm{Th}$ data with simulated sedimentary ${ }^{231} \mathrm{~Pa} /{ }^{230} \mathrm{Th}$. We show that the deep Atlantic circulation during these interstadials was very different from that of the Holocene. Northern-sourced waters likely circulated above $2500 \mathrm{~m}$ depth, with a flow rate lower than that of the presentday North Atlantic deep water (NADW). Southern-sourced deep waters most probably flowed northwards below $4000 \mathrm{~m}$ depth into the North Atlantic basin and then southwards as a return flow between 2500 and $4000 \mathrm{~m}$ depth. The flow rate of this southern-sourced deep water was likely larger than that of the modern Antarctic bottom water (AABW). Our results further show that during Heinrich stadial 2, the deep Atlantic was probably directly affected by a southern-sourced water mass below $2500 \mathrm{~m}$ depth, while a slow, southward-flowing water mass originating from the North Atlantic likely influenced depths between 1500 and $2500 \mathrm{~m}$ down to the equator.
\end{abstract}

\section{Introduction}

Greenland ice core records show that the last glacial climate repeatedly shifted between cold (stadial) and warm (interstadial) conditions (Johnsen et al., 1992). Greenland stadials (GSs) and Greenland interstadials (GIs) are the Greenland expressions of the characteristic millennial-scale DansgaardOeschger events that represent cold and warm phases of the North Atlantic region, respectively (Rasmussen et al., 2014). GSs typically lasted for several centuries and were followed by a rapid warming of up to $15^{\circ} \mathrm{C}$ achieved in (at most) a couple of centuries (Kindler et al., 2014). The subsequent GI then lasted for several centuries to millennia, with Greenland temperatures slowly decreasing and leading to the onset of a new GS. During some of the GSs, icebergs were released from high-latitude Northern Hemisphere ice sheets into the North Atlantic Ocean, and their melting led to the deposition of ice rafted detritus on the seafloor, as observed in marine sediment cores (Heinrich, 1988). We refer to these periods as Heinrich stadials (HSs).

Changes in Atlantic Ocean circulation have long been suggested to impact Greenland temperatures (Broecker et al., 1985) and could be at the origin of the glacial millennialscale variability. Indeed, there is much evidence for de- 
creased North Atlantic deep-water formation and increased influence of southern-sourced deep waters in the Atlantic during Heinrich stadials (Elliot et al., 2002; McManus et al., 2004; Skinner et al., 2003; Vidal et al., 1997). Moreover, climate models are able to reproduce the bipolar seesaw pattern characterizing millennial-scale glacial variability through variations of the strength of the Atlantic meridional overturning circulation (AMOC) in response to freshwater forcings (Ganopolski and Rahmstorf, 2001). However, recent studies show that a shallow circulation cell could have been still active during HSs (Bradtmiller et al., 2014; Gherardi et al., 2009; Lynch-Stieglitz et al., 2014; Roche et al., 2014; Wary et al., 2015), suggesting that Greenland temperature millennial-scale variability might be related to more complex changes in Atlantic circulation than simply switching between "on" and "off" circulation modes. A better understanding of the vertical layout and flow rate of the water masses constituting the AMOC during the last glacial is therefore needed to assess the relationship between AMOC and glacial millennial-scale variability.

Sedimentary $\left({ }^{231} \mathrm{~Pa} /{ }^{230} \mathrm{Th}\right)_{x s, 0}$ (activity ratio of ${ }^{231} \mathrm{~Pa}$ and ${ }^{230} \mathrm{Th}$ unsupported by lithogenic and authigenic uranium and corrected from decay to the time of sediment deposition; $\mathrm{Pa} / \mathrm{Th}$ hereafter) records were first used to assess the AMOC intensity during the last glacial maximum (LGM; Yu et al., 1996). Since then, $\mathrm{Pa} / \mathrm{Th}$ records have been used in the Atlantic to infer changes in the intensity of the deep ocean circulation during HSs (Böhm et al., 2015; Bradtmiller et al., 2014; Burckel et al., 2015; Gherardi et al., 2005, 2009; McManus et al., 2004). The comparison of simulated sedimentary $\mathrm{Pa} / \mathrm{Th}$ values with core top $\mathrm{Pa} / \mathrm{Th}$ data has shown that sedimentary $\mathrm{Pa} / \mathrm{Th}$ reflects circulation intensity in the modern Atlantic Ocean (Lippold et al., 2011).

However, interpretations of sediment $\mathrm{Pa} / \mathrm{Th}$ from a single core can be ambiguous because similar values can result from different geometry and overturning strength (Luo et al., 2010). Reconstructing past circulation thus requires combining $\mathrm{Pa} / \mathrm{Th}$ records from multiple sites over a wide range of latitudes and depths (Gherardi et al., 2009; Lippold et al., 2011, 2012).

In this study, we present new sedimentary $\mathrm{Pa} / \mathrm{Th}$ data from a deep sediment core recovered from the Brazilian margin and from an intermediate depth core from the midlatitude North Atlantic. We then compare the last glacial Pa / Th records from different water depths and latitudes with $\mathrm{Pa} / \mathrm{Th}$ values simulated using a simple 2-D box model (Luo et al., 2010) forced by various stream functions. One stream function is derived from present-day geostrophic velocity estimates (Talley et al., 2003) and two others were simulated with the Earth System model iLOVECLIM under different climatic conditions (Roche et al., 2014). Results of this comparison allow us to constrain the geometry and strength of the AMOC during GI-3, GI-8, GI-10 (Rasmussen et al., 2014) and HS2. We chose to focus our study on HS2 and the interstadials surrounding HS2 and HS4 as these periods are asso- ciated with very different ice-sheet volumes (Lambeck and Chappell, 2001).

\section{Material and methods}

\subsection{Sediment cores}

Sediment cores MD09-3257 (04 $14.69^{\prime} \mathrm{S}, 36^{\circ} 21.18^{\prime} \mathrm{W}$; $2344 \mathrm{~m}$ water depth) and MD09-3256Q $\left(03^{\circ} 32.81^{\prime} \mathrm{S}\right.$, $35^{\circ} 23.11^{\prime} \mathrm{W}$; $3537 \mathrm{~m}$ water depth) were recovered from the Brazilian margin during R/V Marion Dufresne cruise MD173/RETRO3 (Fig. 1). Improved recovery of deep-sea sediments with no or little deformation of sediment layers was achieved during this coring cruise thanks to the systematic use of the CINEMA software (Bourillet et al., 2007; Woerther and Bourillet, 2005). This software computes the amplitude and duration of the elastic recoil of the aramid cable and the piston displacement throughout the coring phase, accounting for the length of the cable (water depth) and total weight of the coring system. The length of the coring cable is indeed of primary importance regarding the deformation rate of the Calypso long piston cores (Bourillet et al., 2007; Skinner and McCave, 2003).

Core GeoB3910 (04 $14.7^{\prime} \mathrm{S}, 36^{\circ} 20.7^{\prime} \mathrm{W}$; $2362 \mathrm{~m}$ water depth; Jaeschke et al., 2007) was recovered from approximately the same position and depth as core MD09-3257, during the Meteor cruise M34/4. Hereafter, we refer to both GeoB3910 and MD09-3257 as intermediate equatorial cores and to MD09-3256Q as the deep equatorial core. At present, the Brazilian margin at these depths is bathed by the North Atlantic deep water (NADW; Fig. 1). Because the Brazilian margin is affected by western boundary currents (Rhein et al., 1995), these sediment cores are ideally located to observe changes in the strength and extent of the intermediate and deep AMOC water masses (Schott, 2003).

Sediment core SU90-03 (40³0.3' N, 32 3.198' W; $2475 \mathrm{~m}$ water depth) was recovered from the northern margin of the subtropical gyre (Chapman et al., 2000). Its location in the midlatitude North Atlantic provides information on changes in NADW production rates that could not be deduced from the sole equatorial depth transect.

We compare these $\mathrm{Pa} / \mathrm{Th}$ records with published records from other Atlantic cores that span the $20-50 \mathrm{ka}$ period: ODP Leg 172 site $1063\left(33^{\circ} 41^{\prime} \mathrm{N}, 57^{\circ} 37^{\prime} \mathrm{W} ; 4584 \mathrm{~m}\right.$ water depth; hereafter, ODP1063) (Böhm et al., 2015); MD022594 (344ㄴ ${ }^{\prime} \mathrm{S}, 17^{\circ} 20^{\prime} \mathrm{E}$; $2440 \mathrm{~m}$ water depth) (Negre et al., 2010) and V29-172 $\left(33^{\circ} 42^{\prime} \mathrm{N}, 2^{\circ} 22.98^{\prime} \mathrm{W} ; 3457 \mathrm{~m}\right.$ water depth) (Bradtmiller et al., 2014) (Fig. 1, Table S1 in the Supplement).

\subsubsection{Benthic $\delta^{13} \mathrm{C}$}

The stable carbon isotopic composition $\left(\delta^{13} \mathrm{C}\right)$ of the epifaunal benthic foraminifer Cibicides wuellerstorfi has been shown to record the $\delta^{13} \mathrm{C}$ of bottom-water dissolved inor- 
(a)

\section{eWOCE}

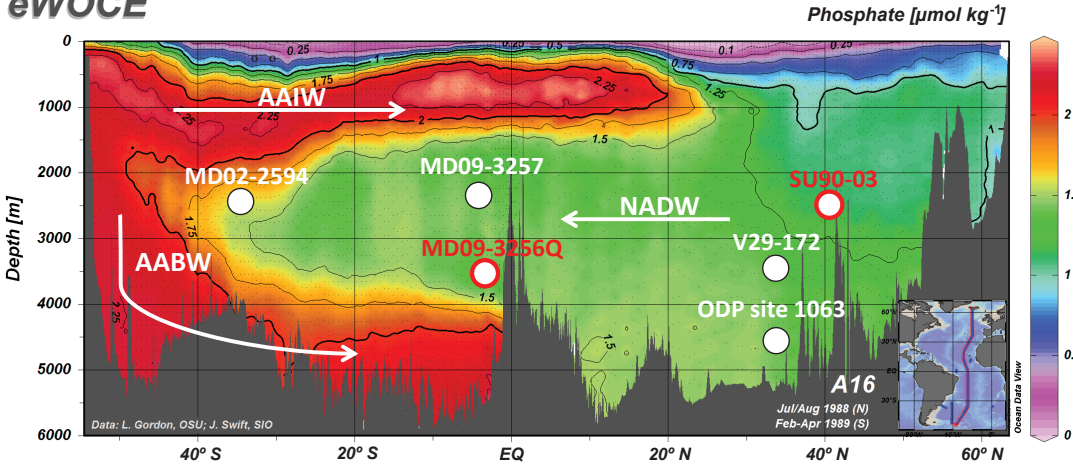

(b)

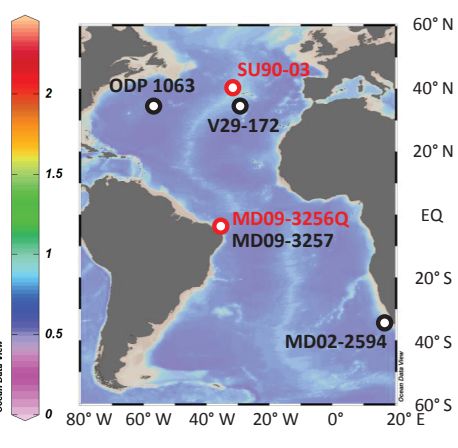

Figure 1. (a) Phosphate section (Schlitzer, 2000) and (b) map of the Atlantic Ocean showing the location of the studied sediment cores (see Sect. 2.1 or Table S1 for detailed locations). Cores, for which we provide new $\mathrm{Pa} / \mathrm{Th}$ or $\delta^{13} \mathrm{C}$ data, are circled in red. Phosphate content follows the structure of the present-day AMOC. White arrows indicate the approximate flow directions of the Antarctic intermediate water (AAIW), Antarctic bottom water (AABW) and North Atlantic deep water (NADW).

ganic carbon (DIC) with minor isotopic fractionation (Duplessy et al., 1984; Zahn et al., 1986). Initial DIC isotopic concentration is acquired by a water mass in its formation region by surface productivity (which consumes ${ }^{12} \mathrm{C}$ therefore increasing dissolved $\delta^{13} \mathrm{C}$ ) and temperature-dependent air-sea interactions (Lynch-Stieglitz et al., 1995; Rohling and Cooke, 2003). DIC $\delta^{13} \mathrm{C}$ then evolves as deep water ages, because the constant export of ${ }^{12} \mathrm{C}$-enriched biogenic material that is remineralized at depth leads to the decrease of the DIC $\delta^{13} \mathrm{C}$ along the flow path of the water mass. As DIC $\delta^{13} \mathrm{C}$ largely follows water mass structure and circulation in the modern ocean, $C$. wuellerstorfi $\delta^{13} \mathrm{C}$ has been used to trace water masses, with a decrease in $C$. wuellerstorfi $\delta^{13} \mathrm{C}$ being interpreted as a decrease in bottom water ventilation, and conversely (e.g., Duplessy et al., 1988). However, the information on bottom water ventilation embedded in $C$. wuellerstorf $\delta^{13} \mathrm{C}$ is complicated by the impact of changes in surface water $\delta^{13} \mathrm{C}$, marine biological productivity and continental biomass changes.

Because LGM $\delta^{13} \mathrm{C}$ values are higher in northern-sourced waters $(1.5 \%)$ than in southern-sourced waters $(<-0.2 \%$; Curry and Oppo, 2005), we interpret a decrease in $C$. wuellerstorfi $\delta^{13} \mathrm{C}$ values at the equatorial sites as an increase in the time elapsed since the water mass was last in contact with the atmosphere or as an increased influence of nutrient-rich southern-sourced deep waters. Note that because we lack information on past marine productivity changes, we do not account for their potential impact on benthic $\delta^{13} \mathrm{C}$ in the present study.

Core MD09-3256Q benthic foraminifer C. wuellerstorfi were handpicked in the size fraction higher than $250 \mu \mathrm{m}$, washed with methanol in an ultrasonic bath and then roasted in glass vials at $380^{\circ} \mathrm{C}$ under vacuum for $45 \mathrm{~min}$. C. wuellerstorfi $\delta^{13} \mathrm{C}$ (expressed in \%o VPDB) was measured at LSCE (Gif-sur-Yvette) using an Elementar Isoprime mass spec- trometer. VPDB is defined with respect to NBS-19 calcite standard $\left(\delta^{18} \mathrm{O}=-2.20\right.$ and $\delta^{13} \mathrm{C}=+1.95 \%$; Coplen, $1988)$. The mean external reproducibility $(1 \sigma)$ of carbonate standards is \pm 0.05 for $\delta^{18} \mathrm{O}$ and $\pm 0.03 \%$ for $\delta^{13} \mathrm{C}$. Measured NBS- $18 \delta^{18} \mathrm{O}$ is $-23.2 \pm 0.2$ VPDB and $\delta^{13} \mathrm{C}$ is $-5.0 \pm 0.1 \%$ VPDB. $\delta^{13} \mathrm{C}$ measurements were done at the highest possible resolution, depending on the availability of C. wuellerstorfi (usually every 1 to $2 \mathrm{~cm}$ ).

\subsubsection{Sedimentary $\mathrm{Pa} / \mathrm{Th}$}

In contrast to $C$. wuellerstorfi $\delta^{13} \mathrm{C}$, which reflects the nutrient content of bottom waters, sedimentary $\mathrm{Pa} / \mathrm{Th}$ is a relatively recent tracer that can be used to estimate the renewal rate of water masses occupying the first $\sim 1000 \mathrm{~m}$ above the seafloor (Thomas et al., 2006; Luo et al., 2010). This tracer has been successfully used to reconstruct past changes in deep Atlantic circulation intensity (Böhm et al., 2015; Gherardi et al., 2005, 2009; Guihou et al., 2010, 2011; Hall et al., 2006; Jonkers et al., 2015; Lippold et al., 2011, 2012; McManus et al., 2004; Negre et al., 2012; Yu et al., 1996).

${ }^{231} \mathrm{~Pa}$ and ${ }^{230} \mathrm{Th}$ are produced at a constant $\mathrm{Pa} / \mathrm{Th}$ activity ratio of 0.093 by dissolved uranium, which is homogeneously distributed in the oceans. ${ }^{230} \mathrm{Th}$ is however much more particle reactive than ${ }^{231} \mathrm{~Pa}$, as reflected by their respective residence time in the ocean $\left(30-40\right.$ years for ${ }^{230} \mathrm{Th}$, 200 years for ${ }^{231} \mathrm{~Pa}$; Francois, 2007). ${ }^{230} \mathrm{Th}$ is therefore rapidly removed from the water column to the underlying sediment, while ${ }^{231} \mathrm{~Pa}$ can be advected by oceanic currents. High (low) rates of overturning therefore result in high (low) ${ }^{23} \mathrm{~Pa}$ export and hence low (high) sedimentary $\mathrm{Pa} / \mathrm{Th}$ ratio in the Atlantic. However, affinities of ${ }^{231} \mathrm{~Pa}$ and ${ }^{230} \mathrm{Th}$ for settling particles depend on the particle type (Chase et al., 2002). For instance, ${ }^{231} \mathrm{~Pa}$ has a high affinity for opal, so that high opal fluxes can result in high sedimentary $\mathrm{Pa} / \mathrm{Th}$ values even in the presence of lateral advection (Chase et al., 2002). 
The origin of sedimentary $\mathrm{Pa} / \mathrm{Th}$ variability therefore needs to be carefully assessed.

$\mathrm{Pa} / \mathrm{Th}$ measurements on core MD09-3256Q were performed by isotopic dilution mass spectrometry on a Thermo Finnigan MC-ICP-MS Neptune, following the method of Guihou et al. (2010).

Core SU90-03 sedimentary $\mathrm{Pa} / \mathrm{Th}$ was measured by isotopic dilution on a single collector, sector field ICP-MS (Element2) at the University of British Columbia, following the procedure described by Choi et al. (2001).

For both cores, $\mathrm{Pa}$ and $\mathrm{Th}$ are corrected from radioactive decay since the time of sediment deposition and from authigenic and lithogenic components using a ${ }^{238} \mathrm{U} /{ }^{232} \mathrm{Th}$ ratio of $0.5 \pm 0.1$ (Fig. S1 in the Supplement; Guihou et al., 2010).

\subsubsection{Age model}

Over the period 0-34 ka, core MD09-3256Q age model is based on $11{ }^{14} \mathrm{C}$ dates measured on planktic foraminifer $G$. ruber white and converted to calendar age using the Marine 13 curve with no additional reservoir age correction (Burckel et al., 2016; Reimer et al., 2013; Fig. S2). During the last glacial, Heinrich stadials were recorded in marine sediment cores from the Brazilian margin as $\mathrm{Ti} / \mathrm{Ca}$ peaks resulting from increased terrigenous input during periods of increased precipitation associated with southward shifts in the position of the intertropical convergence zone (ITCZ; Jaeschke et al., 2007). Ti / Ca peaks are therefore good stratigraphic markers for correlating sediment cores with neighboring well-dated cores. Therefore, from 34 to $50 \mathrm{ka}$, core MD09-3256Q was dated by correlation of its $\mathrm{Ti} / \mathrm{Ca}$ record with that of core GeoB3910 using two tie points corresponding to the $\mathrm{Ti} / \mathrm{Ca}$ peaks associated with HS4 and HS5. The GeoB3910 age model over the 34 to $50 \mathrm{ka}$ period is based on one ${ }^{14} \mathrm{C}$ date calibrated using the Marine 13 curve and on four speleothem tie points at the onset and end of HS4 and HS5 (Burckel et al., 2015). Core MD09-3256Q age model and sedimentation rates are given in Table S2 and Fig. S3. The age model of core SU90-03 is based on $17{ }^{14} \mathrm{C}$ dates measured on various species of planktic foraminifera (Chapman et al., 2000) that were converted to calendar ages using Marine13 calibration curve with no additional reservoir age correction.

${ }^{14} \mathrm{C}$ dates of all the published Atlantic cores used in this study were converted into calendar ages using the same method (Table S1).

\subsection{Circulation and $\mathrm{Pa} / \mathrm{Th}$ model}

\subsubsection{Description of the models}

In order to assess the vertical layout and renewal rate of the water masses constituting the AMOC during the last glacial period, the sedimentary $\mathrm{Pa} / \mathrm{Th}$ data of the studied sediment cores were compared to $\mathrm{Pa} / \mathrm{Th}$ values simulated with a simple 2-D box model (Luo et al., 2010) forced by different stream functions (Fig. 2b, d, f). Stream functions were generated using the iLOVECLIM coupled climate model, comprising atmosphere, ocean and vegetation components (Roche et al., 2014). A LGM equilibrium state computed using the PMIP-2 protocol was used as background climate (see Roche et al., 2007) for details). Stream functions characterized by a shallow $(<2500 \mathrm{~m})$ northern-sourced overturning cell (shallow overturning stream function) and by a complete shutdown of the AMOC (off-mode stream function) were generated by imposing a 0.16 and $0.35 \mathrm{~Sv}$ freshwater forcing in the Labrador Sea, respectively (Roche et al., 2010, 2014). The freshwater input is added during 300 years on the LGM background state. The stream functions are taken as the mean over the 100-year period of lowest deep-water formation in the North Atlantic, during or right after the period of freshwater forcing. A freshwater input of $0.16 \mathrm{~Sv}$ allows the presence of a shallow circulation cell in the Atlantic Ocean, while a freshwater forcing of $0.35 \mathrm{~Sv}$ leads to an almost complete shutdown of the AMOC (Roche et al., 2014). Note that the freshwater input values needed to modify the AMOC are strongly model dependent and the important information carried by the model in the present context is the state of the AMOC rather than the freshwater input value. Contrary to shallow overturning and off-mode stream functions, the Holocene stream function was computed using data-based geostrophic velocity estimates (Talley et al., 2003).

Dissolved $\mathrm{Pa}$ and Th concentrations in the 2-D box model are controlled by (1) production from $U$ decay in the water column, (2) adsorption and desorption on settling particles and (3) advection by oceanic circulation. Particulate $\mathrm{Pa}$ and Th concentrations are controlled by (1) adsorption and desorption from the dissolved pool and (2) removal of sedimentary particles to the seafloor (Luo et al., 2010).

Modeled sedimentary meridional $\mathrm{Pa} / \mathrm{Th}$ sections generated with the different stream functions are shown in Fig. 2a, c, e. Different water mass circulation intensities and geometries result in different simulated sedimentary $\mathrm{Pa} / \mathrm{Th}$ (Luo et al., 2010). In the deep Atlantic, increasing circulation intensity above a specific location causes $\mathrm{Pa} / \mathrm{Th}$ to decrease at that water depth because of the increased $\mathrm{Pa}$ export and conversely. Increasing water depth without modifying circulation intensity also causes sedimentary $\mathrm{Pa} / \mathrm{Th}$ ratio to decrease in the model because of the increased residence time of $\mathrm{Pa}$ and resulting higher Pa export, and conversely. Finally, the sedimentary $\mathrm{Pa} / \mathrm{Th}$ ratio increases along the flow path of any newly formed water mass as low dissolved Pa concentrations of newly formed water masses increase by desorption of $\mathrm{Pa}$ from Pa-concentrated settling particles equilibrating with ambient waters (Francois, 2007). Adsorption and desorption rate constants also impact the simulated $\mathrm{Pa} / \mathrm{Th}$ ratio. These constants were adjusted to reflect the opal belt in the Southern Ocean (Luo et al., 2010). For the Holocene, these constants were also changed to reflect preferential scavenging of Pa by biogenic opal in the northern North Atlantic (Lippold et al., 2012). 

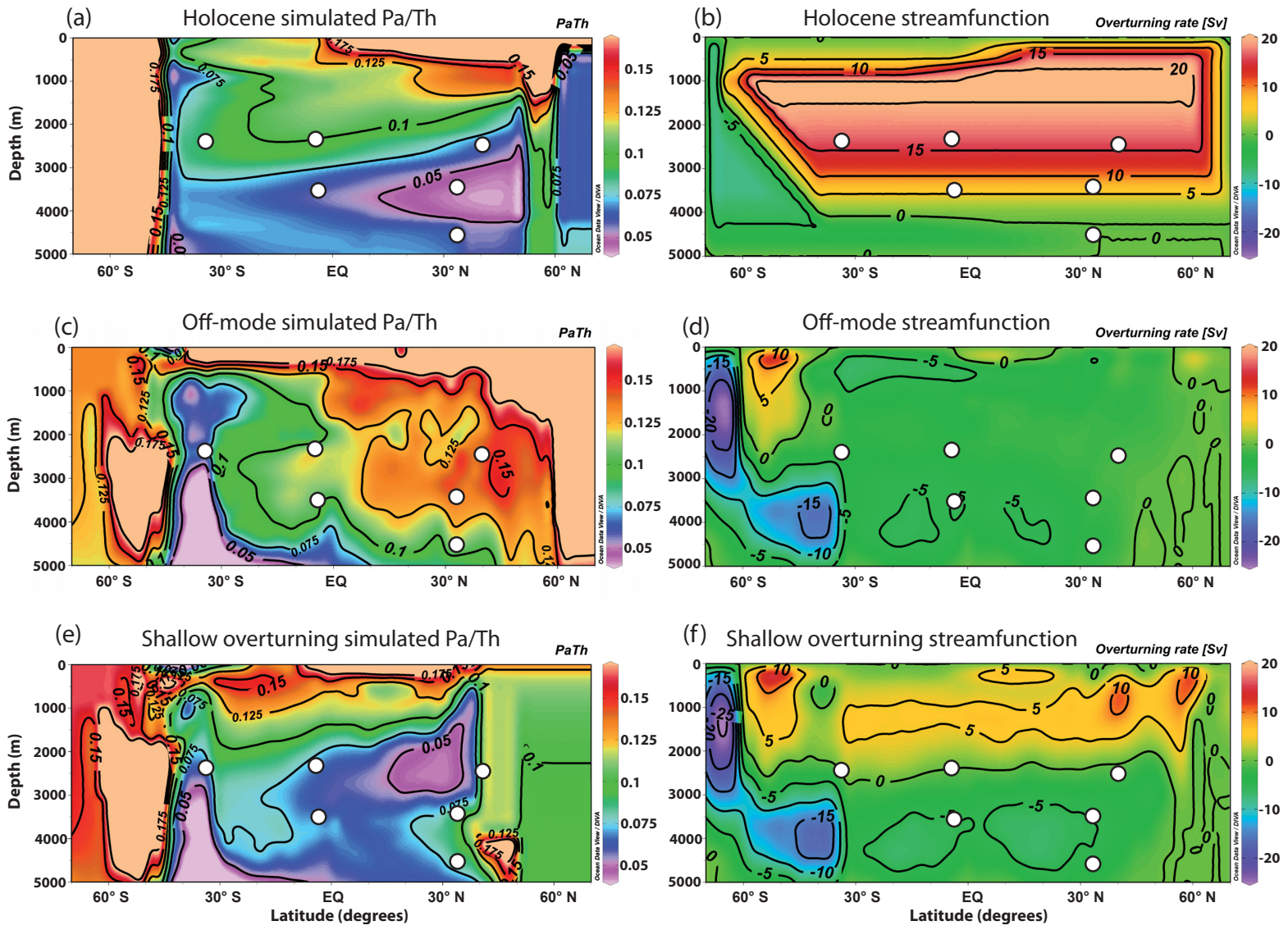

Figure 2. Simulated sedimentary Pa / Th values (left) in response to different stream functions (right): (a, b) Holocene, (c, d) off-mode, (e, f) shallow overturning. White dots indicate the position of the studied sediment cores (see Fig. 1). Data gridding was achieved using the Ocean Data View software (Schlitzer, 2015).

\subsubsection{Limits of the models}

The absence of margins in the simple 2-D Pa / Th model (Luo et al., 2010) prevents it from simulating boundary scavenging, which is the lateral advection of dissolved $\mathrm{Pa}$ from open ocean regions characterized by high Pa concentrations to coastal regions of low $\mathrm{Pa}$ concentration such as in upwelling zones (Christl et al., 2010). However, as described in the results section below, we verified that our $\mathrm{Pa} / \mathrm{Th}$ signal is mainly driven by oceanic circulation changes and the importance of diffusive transport is therefore likely negligible here. This simple 2-D Pa / Th model therefore appears adequate for comparison with our $\mathrm{Pa} / \mathrm{Th}$ data. The vertical resolution of the iLOVECLIM model is depth dependent, with higher resolution (10 to $100 \mathrm{~m}$ ) in the upper water column than below $1000 \mathrm{~m}$ (500 to $700 \mathrm{~m})$. Hence, the uncertainty in the position of the water mass transitions in the stream functions below $1000 \mathrm{~m}$ is of 500 to $700 \mathrm{~m}$. However, because sedimentary Pa / Th likely reflects the Pa export in the bottom $1000 \mathrm{~m}$ of the water column (Thomas et al., 2006), the model vertical resolution is sufficient to properly simulate sedimentary $\mathrm{Pa} / \mathrm{Th}$ values. Hence, the relatively low verti- cal resolution of the iLOVECLIM model in the deep ocean does not affect our conclusions.

\subsection{Time slice definition}

We define three interstadial time slices and one Heinrich stadial time slice (Fig. 3) to compare Pa / Th data measured in Atlantic cores to $\mathrm{Pa} / \mathrm{Th}$ values simulated with the different stream functions. We focus on HS2, the preceding GI and the GIs bracketing HS4. We did not include HS4 in our study because core MD09-3257 HS4 Pa / Th data are affected by boundary scavenging (see Sect. 3.1, Burckel et al., 2015) and we therefore lack information from an important location of the Atlantic Ocean.

GI-3, GI-8 and GI-10 time slices are defined as the periods of stable sedimentary $\mathrm{Pa} / \mathrm{Th}$ values in core MD09-3257 associated with the NGRIP GI time intervals (Fig. 3). More specifically, we used as a reference MD09-3257 Pa / Th values bracketing the middle of NGRIP GI time intervals in the GICC05 age scale (Rasmussen et al., 2014). Contiguous $\mathrm{Pa} / \mathrm{Th}$ values within $1 \sigma$ uncertainty of the $\mathrm{Pa} /$ Th reference value form a plateau of stable $\mathrm{Pa} / \mathrm{Th}$ values that was used to 


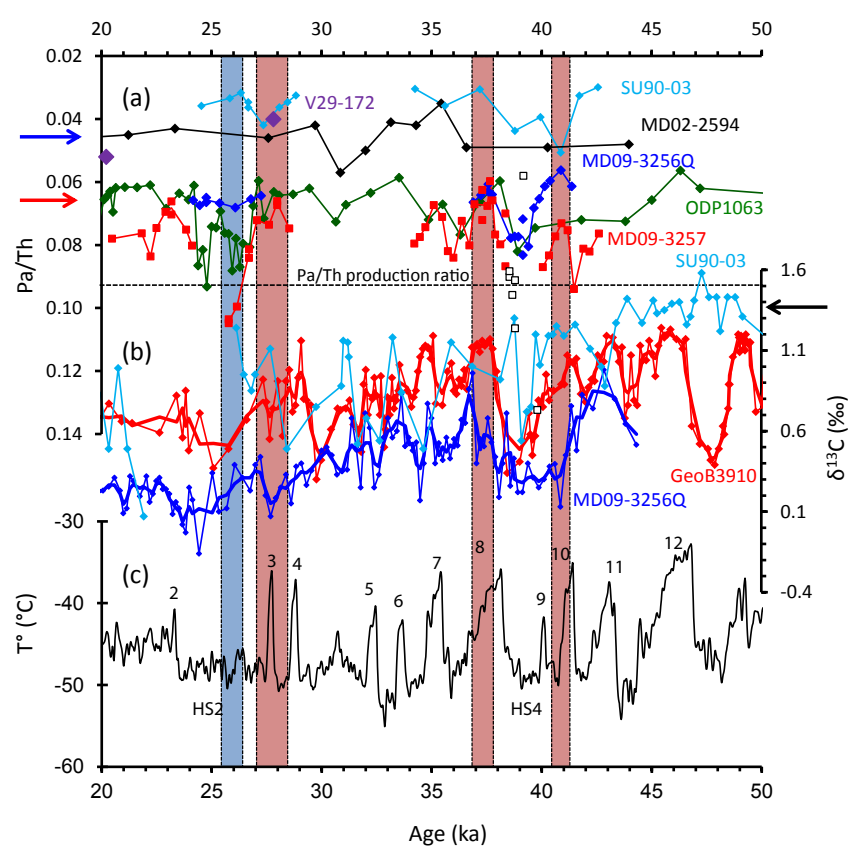

Figure 3. Comparison between sedimentary $\mathrm{Pa} / \mathrm{Th}$ and benthic $\delta^{13} \mathrm{C}$ data from the Brazilian margin, Bermuda Rise, midlatitude North Atlantic Ocean and South Atlantic Ocean and Greenland temperatures. (a) MD09-3256Q (this study), SU90-03 (this study), MD09-3257 (Burckel et al., 2015), ODP1063 (Böhm et al., 2015), MD02-2594 (Negre et al., 2010) and V29-172 (Bradtmiller et al., 2014) Pa / Th; (b) MD09-3256Q (this study), SU90-03 (Chapman et al., 2000) and GeoB3910 (Burckel et al., 2015) C. wuellerstorfi $\delta^{13} \mathrm{C}$; and (c) NGRIP temperature record on the GICC05 timescale (Kindler et al., 2014). In (a) lines pass through average $\mathrm{Pa} / \mathrm{Th}$ values in case of replicates, while diamonds and squares (MD09-3257) correspond to individual $\mathrm{Pa} / \mathrm{Th}$ measurements. V29-172 $\mathrm{Pa} / \mathrm{Th}$ values are represented by two purple diamonds. White squares indicate $\mathrm{Pa} / \mathrm{Th}$ values not considered in core MD09-3257, as they might not be influenced by oceanic circulation only (Burckel et al., 2015). The red and blue arrows indicate the late Holocene $\mathrm{Pa} / \mathrm{Th}$ values in cores MD09-3257 (0.065 \pm 0.004 , Burckel et al., 2015) and MD09-3256Q (0.043 \pm 0.002$)$, respectively. Error bars on Pa / Th measurements are given in Fig. S1 and Tables S7 and S8. In (b) thick lines are three-point running averages of the $C$. wuellerstorfi $\delta^{13} \mathrm{C}$ records; the black arrow indicates present-day NADW $\delta^{13} \mathrm{C}$ value $\left(\sim 1.36 \%\right.$; the Supplement). $\delta^{13} \mathrm{C}$ values are given in Table S9. In (c) numbers indicate the GIs. Red vertical bands represent the GI-3, GI-8 and GI-10 time slices and the blue vertical band the HS2 time slice.

define the GI time slices. With this definition, GI time slices represent the periods of stable oceanic circulation associated with each GI. The HS2 time slice was defined in core MD093257 as the period of maximum sedimentary $\mathrm{Pa} / \mathrm{Th}$ after the abrupt rise associated with the onset of HS2.

Sedimentary $\mathrm{Pa} / \mathrm{Th}$ values associated with each time slice and core are given in Table S3. We computed uncertainties on the $\mathrm{Pa} / \mathrm{Th}$ values associated with each time slice accounting for the uncertainty on individual $\mathrm{Pa} / \mathrm{Th}$ measurements and uncertainties on the age model (see the Supplement).

Both GI-8 and GI-10 time slices are associated with high temperatures recorded in Greenland ice cores. The GI-3 time slice includes both the period of high Greenland temperatures associated with GI-3 and periods of low temperatures associated with GS-4 and the beginning of GS-3. Given the low $\mathrm{Pa} / \mathrm{Th}$ and high $\delta^{13} \mathrm{C}$ values in the intermediate equatorial core at that time, we consider that the GI-3 time slice mainly reflects interstadial conditions. However, because temporal resolution of the marine records is too low to clearly distinguish between GI-3 and GS-4, information about the state of the AMOC during GIs derived from this time slice should be considered with caution.

\subsection{Quantification of the model-data agreement}

In order to quantify the agreement between simulated and measured sedimentary $\mathrm{Pa} / \mathrm{Th}$, we compute the Euclidean distance, defined as the square root of the sum of squared differences between simulated and measured $\mathrm{Pa} / \mathrm{Th}$ for each core. Minimum values indicate the best agreement between simulated and measured $\mathrm{Pa} / \mathrm{Th}$ (Tables S4 and S5). Note that due to the limited number of sedimentary $\mathrm{Pa} / \mathrm{Th}$ records during MIS3, we can only provide an approximate estimate of water mass boundary positions. Our equatorial transect is however ideally located to record shifts in the position of the transition between southern- and northern-sourced water masses.

\section{Results}

\subsection{Sedimentary $\mathrm{Pa} / \mathrm{Th}$ data}

Cores MD09-3257, MD09-3256Q and SU90-03 Pa/Th measurements were centered on HS2 and HS4 (Burckel et al., 2016; Fig. 3). No Pa / Th values were measured within HS2 in core MD09-3257 because of the presence of turbidite layers (Burckel et al., 2015). During HS4 and before HS2, the sedimentary $\mathrm{Pa} / \mathrm{Th}$ ratio of core MD09-3257 rises above the production ratio of 0.093 , indicating the absence of $\mathrm{Pa}$ export. $\mathrm{Pa} / \mathrm{Th}$ variability associated with GS and GI is observed, with high $\mathrm{Pa} / \mathrm{Th}$ values occurring during GS and low $\mathrm{Pa} / \mathrm{Th}$ values during GI. $\mathrm{Pa}$ / Th variations in core MD09$3256 \mathrm{Q}$ are more muted (Fig. 3). The main $\mathrm{Pa} / \mathrm{Th}$ variation in core MD09-3256Q occurs during HS4, when Pa / Th values rise from $\sim 0.06$ to $\sim 0.08$. This increase in MD093256Q Pa / Th also corresponds, within dating uncertainties, with the largest $\mathrm{Pa} / \mathrm{Th}$ change from $\sim 0.03$ to $\sim 0.05$ in core SU90-03.

Before interpreting our $\mathrm{Pa} / \mathrm{Th}$ records in terms of ocean circulation changes, we need to assess whether varying lithogenic or opal fluxes impacted the scavenging intensities of $\mathrm{Pa}$ and $\mathrm{Th}$. To do so, we use the preserved opal and ${ }^{232} \mathrm{Th}$ fluxes as tracers for past opal and terrigenous fluxes, respec- 
tively (Anderson et al., 2006; Lippold et al., 2012). Core MD09-3257 Pa / Th data are mainly influenced by oceanic circulation, except during the high lithogenic flux period associated with HS4 $\left({ }^{232} \mathrm{Th}\right.$ flux $>12 \mathrm{dpm} \mathrm{cm}^{-2} \mathrm{ky}^{-1}$, Fig. 3a, white squares; Burckel et al., 2015). In core MD09-3256Q, opal fluxes do not covary with the $\mathrm{Pa} / \mathrm{Th}$ ratio and are very low (0.01-0.02 $\mathrm{g} \mathrm{cm}^{-2} \mathrm{kyr}^{-1}$, Burckel et al., 2016; Table S6; Fig. S4a). In the Atlantic, the lowest opal flux value observed to influence the sedimentary $\mathrm{Pa} / \mathrm{Th}$ ratio is $0.2 \mathrm{~g} \mathrm{~cm}^{-2} \mathrm{kyr}^{-1}$ (Lippold et al., 2012). Hence, given the much lower opal fluxes recorded in core MD09-3256Q and their lack of correlation with sedimentary $\mathrm{Pa} / \mathrm{Th}$, we conclude that biogenic silica had no (or very little) influence on $\mathrm{Pa} / \mathrm{Th}$ variability. Similarly, we find no correlation between ${ }^{232} \mathrm{Th}$ fluxes and $\mathrm{Pa} / \mathrm{Th}$ values in this core $(P$ value $=0.48, n=22 ; \mathrm{Fig}$. S5a $)$. We can therefore safely assume that the $\mathrm{Pa} / \mathrm{Th}$ variability recorded in our equatorial cores is mainly driven by changes in oceanic circulation intensity.

Core SU90-03 opal fluxes are low $\left(<0.1 \mathrm{~g} \mathrm{~cm}^{-2} \mathrm{kyr}^{-1}\right.$, Table S6) and do not show any correlation with $\mathrm{Pa} / \mathrm{Th}$ data $\left(P\right.$ value $=0.52, n=10 ;$ Fig. S4b). In contrast, ${ }^{232}$ Th fluxes could be correlated to the $\mathrm{Pa} / \mathrm{Th}$ signal $(P$ value $=0.03$, $n=16$, Fig. S5b). This correlation is only driven by the highest $\mathrm{Pa} / \mathrm{Th}$ value, and removing this single value results in the disappearance of the correlation ( $P$ value $=0.31, n=15)$. However, we chose to keep this value as SU90-03 ${ }^{232}$ Th flux is low $\left(<\sim 1.5 \mathrm{dpm} \mathrm{cm}^{-2} \mathrm{kyr}^{-1}\right)$ and its $\mathrm{Pa} / \mathrm{Th}$ signal remains low (0.03-0.05) on the entire 20-50 ka period, indicating a constant significant $\mathrm{Pa}$ export through water mass advection. Oceanic circulation is therefore the main process explaining SU90-03 $\mathrm{Pa} / \mathrm{Th}$ data.

The published $\mathrm{Pa} / \mathrm{Th}$ values of other sediment cores used in this study have been shown to be mainly driven by oceanic circulation intensity (Bradtmiller et al., 2014).

\subsection{C. wuellerstorfi $\delta 13 \mathrm{C}$ data}

C. wuellerstorfi $\delta^{13} \mathrm{C}$ of both equatorial cores shows millennial-scale variability, with lower $\delta^{13} \mathrm{C}$ values occurring during HSs (Burckel et al., 2016). GS and GI are also recorded in the $\delta^{13} \mathrm{C}$ record of the intermediate core by low and high $\delta^{13} \mathrm{C}$ values, respectively. In the deep core, the low sedimentation rate induces a low temporal resolution and a smoothing of the $\delta^{13} \mathrm{C}$ signal that may have erased $\delta^{13} \mathrm{C}$ decreases associated with short GSs.

$\delta^{13} \mathrm{C}$ values during the LGM are $0.24 \pm 0.07$ and $0.66 \pm 0.06 \%$ in the deep and intermediate equatorial core, respectively (Fig. 3). Given that the late Holocene $\delta^{13} \mathrm{C}$ measured in the equatorial cores are both close to $1.35 \%$ (see the Supplement), these LGM $\delta^{13} \mathrm{C}$ values are much lower than what would be expected from the $\sim 0.3 \%$ o glacialinterglacial change in mean ocean $\delta^{13} \mathrm{C}$ in response to a reduced continental biosphere during glacial periods (Duplessy et al., 1988). The low $\delta^{13} \mathrm{C}$ values observed during the LGM and some of the GSs could thus indicate either a slow- down of the deep-water circulation, or an increased influence of southern-sourced water masses at both sites during the glacial with respect to the Holocene.

\subsection{Ocean circulation signals}

In cores MD09-3257/GeoB3910, SU90-03 and ODP1063, GI time slices are generally characterized by lower $\mathrm{Pa} / \mathrm{Th}$ and higher $\delta^{13} \mathrm{C}$ values than those characterizing GS periods (Fig. 3). The only exception is GI-10 as this period is associated with a transition from relatively low to high $\mathrm{Pa} / \mathrm{Th}$ values associated with HS4 in core SU90-03. Conversely, the HS2 time slice is associated with high $\mathrm{Pa} / \mathrm{Th}$ values and low $\delta^{13} \mathrm{C}$ values in these cores, except for core SU90-03 that exhibits $\mathrm{Pa} / \mathrm{Th}$ and $\delta^{13} \mathrm{C}$ values similar to GI time slices.

Core MD09-3256Q Pa / Th values are below 0.07 in all the studied time slices, with minor variability even between GI and HS2 time slices. Its $\delta^{13} \mathrm{C}$ record is systematically $0.4-0.5 \%$ o below that of core MD09-3257, even though the $\delta^{13} \mathrm{C}$ difference between the two cores is reduced during HS2. Core MD09-3256Q therefore appears to be constantly bathed by a nutrient-rich water mass exporting dissolved protactinium.

There is only one $\mathrm{Pa} / \mathrm{Th}$ value within our GI time slices in core MD02-2594 (GI-3, Fig. 3). However, two other Pa / Th values can be attributed to both GI-8 and GI-10 as they lie within these time slices considering age model uncertainties. These low MD02-2594 Pa / Th values indicate that, during GI time slices, protactinium was exported away from the intermediate-depth South Atlantic Ocean.

In addition to the above $\mathrm{Pa} / \mathrm{Th}$ records, we use one $\mathrm{Pa} / \mathrm{Th}$ value from core V29-172. This value lies within the GI-3 time slice and is rather low (0.04), similarly to the shallower North Atlantic core SU90-03. This supports the existence of Pa export between 1500 and $3500 \mathrm{~m}$ depth in the North Atlantic during GI-3.

\section{Discussion}

Time slice sedimentary $\mathrm{Pa} / \mathrm{Th}$ data from the six selected Atlantic sediment cores are compared, when available, to the sedimentary $\mathrm{Pa} / \mathrm{Th}$ pattern simulated in response to the different stream functions (Figs. 4-6). We focus in particular on the equatorial cores and describe their modeled and measured sedimentary $\mathrm{Pa} / \mathrm{Th}$ by referring to the vertical $\mathrm{Pa} / \mathrm{Th}$ gradient between 2300 and $3500 \mathrm{~m}$ (i.e., the water depths of the sediment cores). Indeed, vertical $\mathrm{Pa} / \mathrm{Th}$ gradients are useful indicators of the vertical layout of water masses. In what follows, we will see how each vertical gradient can be interpreted. 

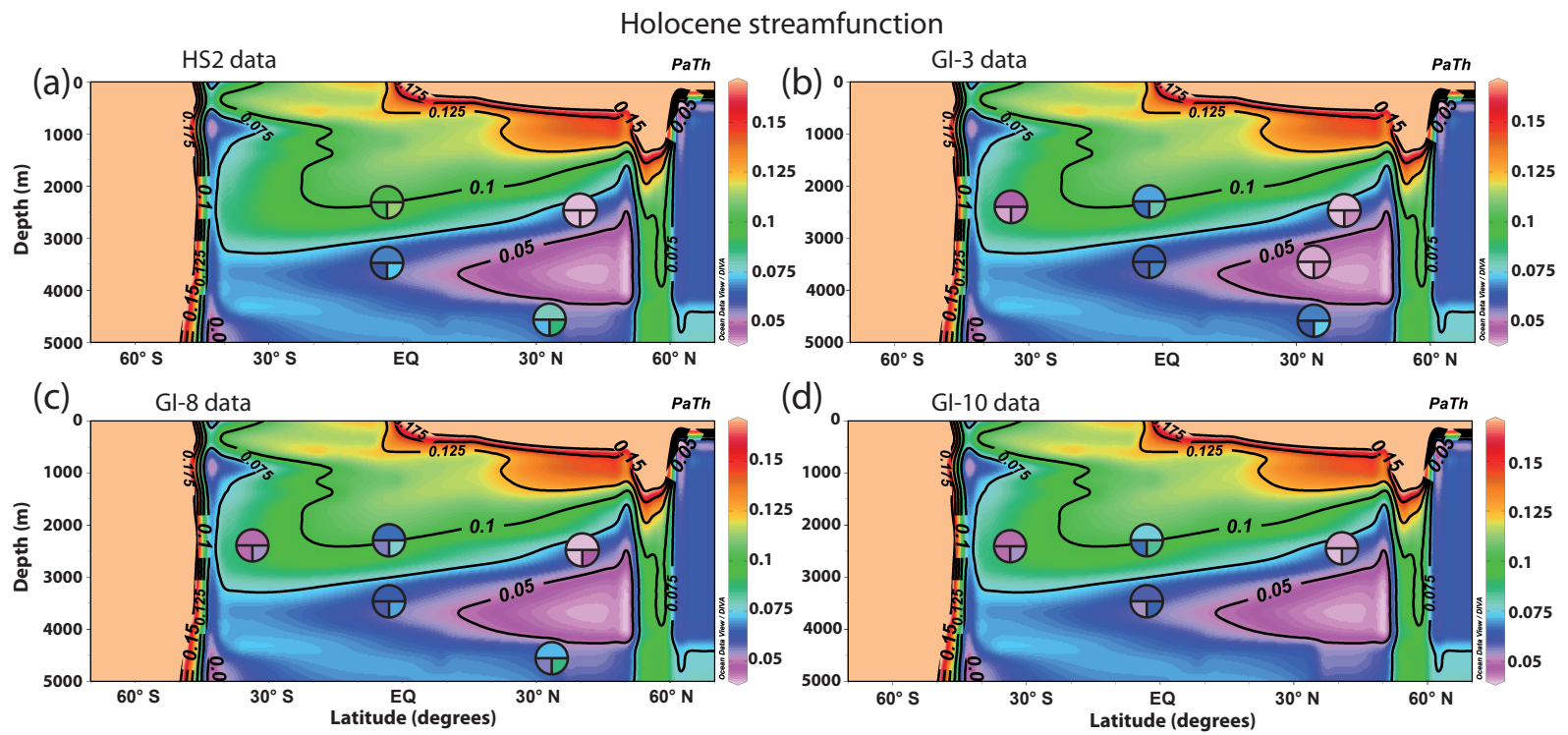

Figure 4. Comparison of the $\mathrm{Pa} / \mathrm{Th}$ data (circles) for each of the time slices to the simulated $\mathrm{Pa} / \mathrm{Th}$ values using the Holocene stream function. (a) HS2, (b) GI-3, (c) GI-8 and (d) GI-10 Pa / Th data. The upper half of the circles represents the Pa / Th mean value, the lower left quarter, the $\mathrm{Pa} / \mathrm{Th}$ mean value $-1 \sigma$, and the lower right quarter represents the $\mathrm{Pa} / \mathrm{Th}$ mean value $+1 \sigma$. Data gridding was achieved using the Ocean Data View software (Schlitzer, 2015).

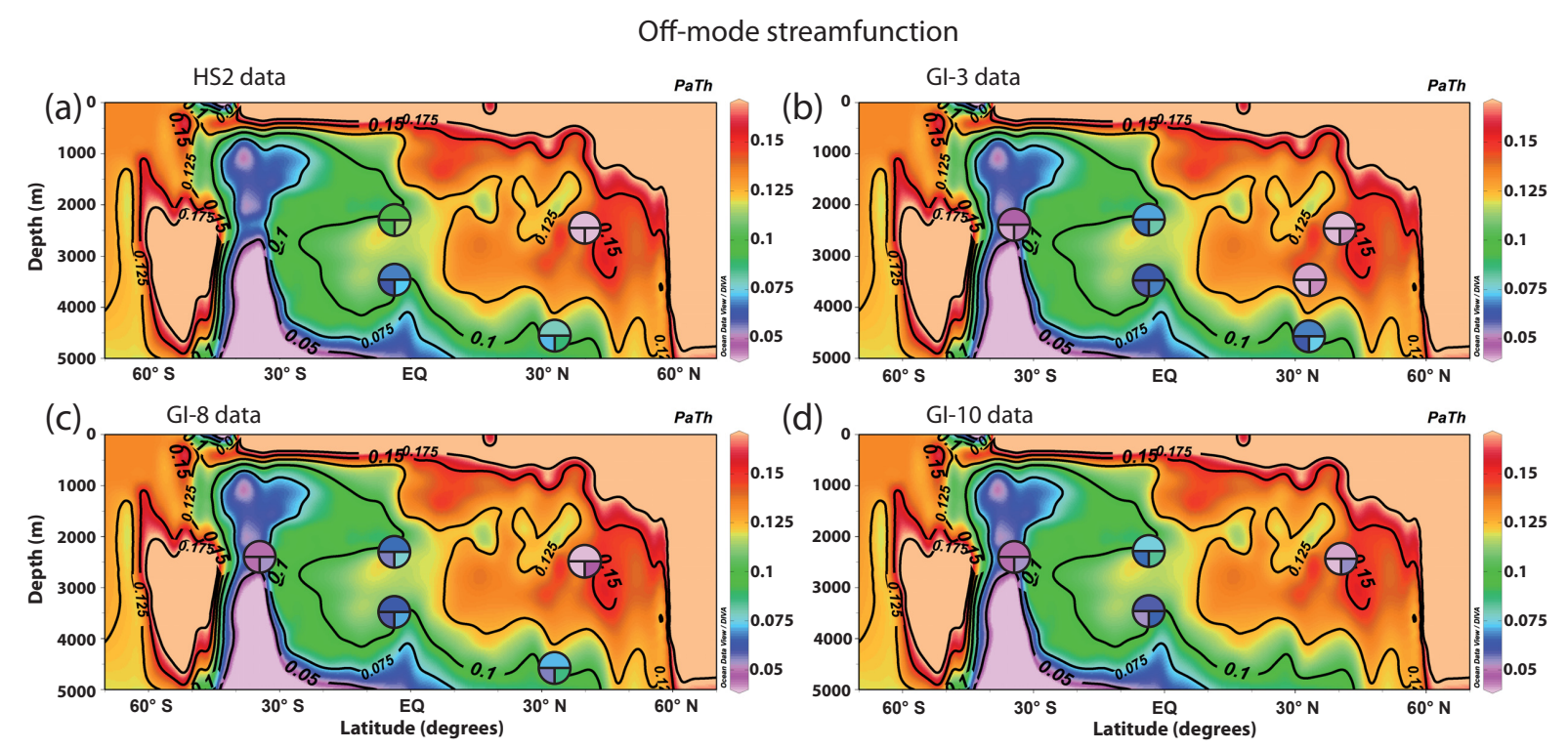

Figure 5. Comparison of the $\mathrm{Pa} / \mathrm{Th}$ data for each of the time slices to the simulated $\mathrm{Pa} / \mathrm{Th}$ values using the off-mode stream function. Time slices are (a) HS2, (b) GI-3, (c) GI-8 and (d) GI-10 Pa / Th data; symbols are as in Fig. 4.

\subsection{Greenland interstadials (GI-3, GI-8 and GI-10 time slices)}

\subsubsection{Comparison with the Holocene simulation}

A large vertical $\mathrm{Pa} / \mathrm{Th}$ gradient between the two equatorial core sites is simulated by the model in the presence of a southward-flowing northern-sourced deep water mass such as NADW in the Holocene simulation (Fig. 4). This is due to the fact that the sedimentary $\mathrm{Pa} / \mathrm{Th}$ ratio decreases with depth within a single water mass of uniform flow rate. This effect is intensified in the case of the Holocene stream function, as the flow rate of NADW is not uniform but stronger between 2500 and $3500 \mathrm{~m}$ and weaker between 1300 and $2300 \mathrm{~m}$ (acquisition depths of sedimentary $\mathrm{Pa} / \mathrm{Th}$ for the deep and intermediate cores, respectively). Hence, Pa export at $3500 \mathrm{~m}$ is more intense than at $2300 \mathrm{~m}$, thereby signifi- 

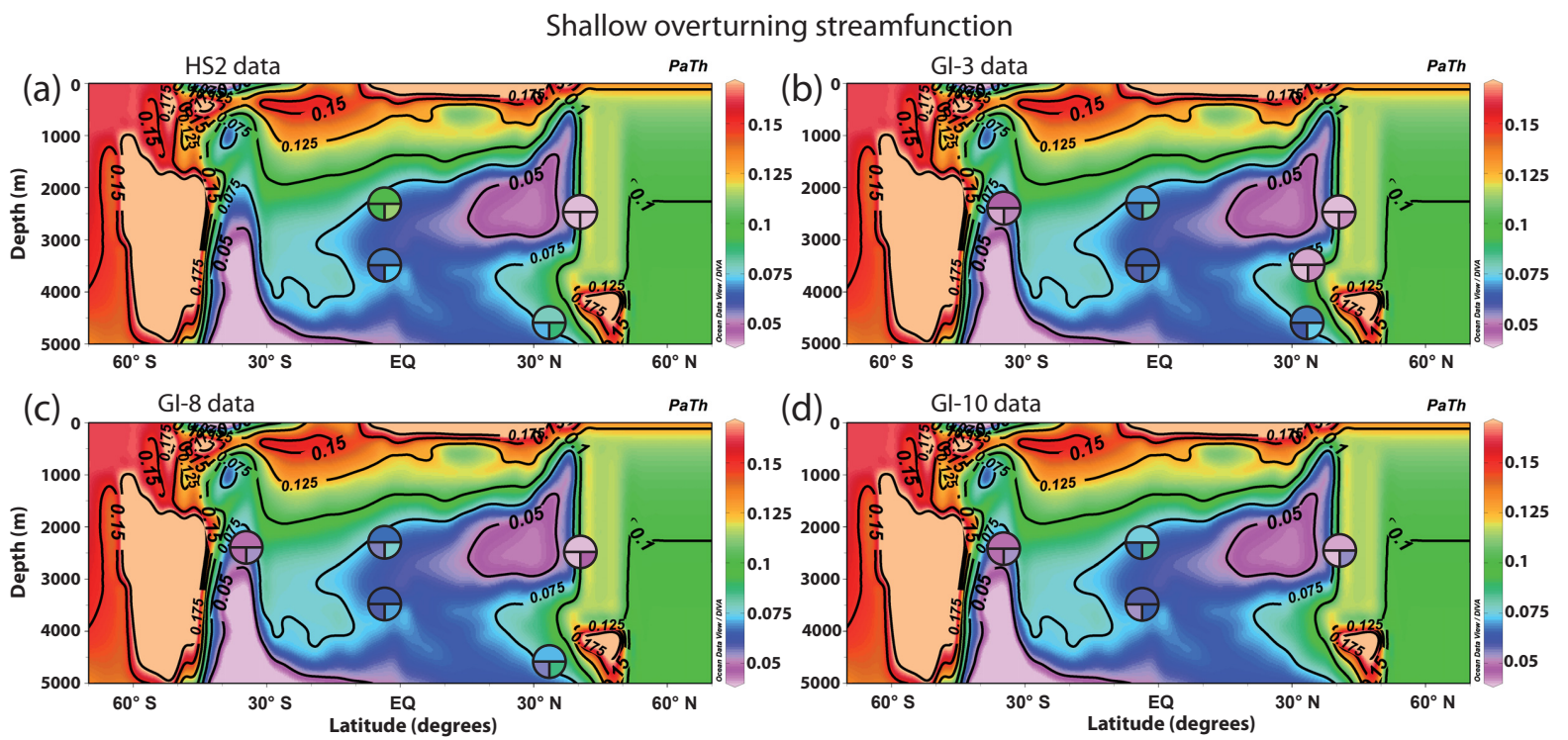

Figure 6. Comparison of the $\mathrm{Pa} / \mathrm{Th}$ data for each of the time slices to the simulated $\mathrm{Pa} / \mathrm{Th}$ values using the shallow overturning stream function. Time slices are (a) HS2, (b) GI-3, (c) GI-8 and (d) GI-10 Pa / Th data; symbols are as in Fig. 4.

cantly increasing the vertical $\mathrm{Pa} / \mathrm{Th}$ gradient between the two cores.

Interstadial $\mathrm{Pa} / \mathrm{Th}$ data in the deep equatorial and North Atlantic cores are consistent with simulated $\mathrm{Pa} / \mathrm{Th}$ values obtained with the Holocene stream function (Fig. 4b-d). However, interstadial sedimentary $\mathrm{Pa} / \mathrm{Th}$ values in the equatorial core at intermediate depth are lower than predicted by the $\mathrm{Pa} / \mathrm{Th}$ model forced with the Holocene stream function. The vertical $\mathrm{Pa} / \mathrm{Th}$ gradient between our equatorial cores during interstadials is small, which is in contradiction with the large vertical $\mathrm{Pa} / \mathrm{Th}$ gradient simulated with the Holocene stream function. Moreover, data from Southern Ocean core MD02-2594 are systematically between 0.045 and 0.050 during GI (Fig. 3) and are in conflict with the high Holocene $\mathrm{Pa} / \mathrm{Th}$ value $(\sim 0.09)$ simulated at this core site (Fig. 4).

High $\delta{ }^{13} \mathrm{C}$ values in the intermediate equatorial core during MIS3 interstadials suggest that northern-sourced deep waters influenced the equatorial Atlantic at $2300 \mathrm{~m}$ depth (Fig. 3b). However, the lower $\delta^{13} \mathrm{C}$ values of the deep equatorial core imply that, unlike in the present-day Atlantic, nutrient-rich southern-sourced deep waters were present at $3500 \mathrm{~m}$ depth in the equatorial West Atlantic.

Therefore, both $\mathrm{Pa} / \mathrm{Th}$ and $\delta^{13} \mathrm{C}$ data indicate that the geometry and strength of the AMOC during the studied GI were different from those of the Holocene.

\subsubsection{Comparison with the off-mode simulation}

$\mathrm{Pa} / \mathrm{Th}$ values simulated with the off-mode stream function exhibit a small vertical $\mathrm{Pa} / \mathrm{Th}$ gradient between the two equatorial cores (Fig. 5). However, the sedimentary $\mathrm{Pa} / \mathrm{Th}$ values measured during interstadials are much lower than the simulated values at both equatorial sites and in the North Atlantic Ocean. These low measured $\mathrm{Pa} / \mathrm{Th}$ values imply a significant export of $\mathrm{Pa}$ by oceanic circulation and therefore exclude the possibility of an almost halted deep Atlantic circulation above $3500 \mathrm{~m}$ depth (Fig. 5b-d).

In addition, while in the off-mode stream function no significant deep convection occurs in the high-latitude North Atlantic, the high $\delta^{13} \mathrm{C}$ values of core SU90-03 and MD093257 and low $\delta^{13} \mathrm{C}$ values of core MD02-2594 (<0.5\%o, Negre et al., 2010), indicate that northern-sourced waters were present at $\sim 2500 \mathrm{~m}$ in the North and equatorial Atlantic (Fig. 3).

Hence, it is highly unlikely that the off-mode stream function depicts the deep Atlantic circulation during the studied GI.

\subsubsection{Comparison with the shallow overturning simulation}

The shallow overturning stream function also induces a small vertical $\mathrm{Pa} / \mathrm{Th}$ gradient between the equatorial records (Fig. 6). In contrast to the simulation obtained with the off-mode stream function, this small vertical $\mathrm{Pa}$ / Th gradient is associated with significant lateral export of $\mathrm{Pa}$ at the depth of both the intermediate and deep equatorial cores, as well as at the Bermuda Rise and Southern Ocean cores, in agreement with $\mathrm{Pa} / \mathrm{Th}$ data (Fig. 6b-d). Such a small vertical $\mathrm{Pa} / \mathrm{Th}$ gradient is simulated in the case of two water masses overlying each other and flowing in opposite directions (Fig. S6; Lippold et al., 2012). Indeed, in the shallow overturning stream function, northern-sourced waters affect 
the depth of the intermediate equatorial core (above $2500 \mathrm{~m}$ ). Below $\sim 4000 \mathrm{~m}$, northward-flowing, southern-sourced waters are active and can lead to a return flow (between 2500 and $4000 \mathrm{~m}$ depth) that influences the depth of the deep equatorial core (3500 m; Fig. 2e, f). This circulation scheme results in decreasing or invariant lateral export of $\mathrm{Pa}$ with depth, which in turns causes sedimentary $\mathrm{Pa} / \mathrm{Th}$ to increase or to be constant with depth at the equator.

However, the agreement between simulated and measured $\mathrm{Pa} / \mathrm{Th}$ in the Atlantic Ocean cores is lower (i.e., larger Euclidean distances, Table S4) with the shallow overturning stream function than with the Holocene stream function. The better model-data agreement obtained with the Holocene stream function is driven by the $\mathrm{Pa} / \mathrm{Th}$ data of the intermediate and deep midlatitude North Atlantic cores (SU90-03 and V29-172), as the deep convection of NADW induces low modeled $\mathrm{Pa} / \mathrm{Th}$ values south of $50^{\circ} \mathrm{N}$. In the shallow overturning stream function, the region of deep-water formation is shifted southward (Fig. 2). In the Pa / Th model, dissolved protactinium and thorium concentrations are therefore vertically homogenized between 40 and $60^{\circ} \mathrm{N}$ (against $60-70^{\circ} \mathrm{N}$ in the case of the Holocene stream function), preventing the presence of low sedimentary $\mathrm{Pa} / \mathrm{Th}$ values north of $\sim 40^{\circ} \mathrm{N}$. A southward shift in the deep convection zone during the last glacial has been observed in earlier studies (e.g., Vidal et al., 1997), but the simulated southward shift in the present shallow overturning stream function could be overestimated. Assuming a more northerly position of the region of deepwater formation, the $\mathrm{Pa} / \mathrm{Th}$ observed in the North Atlantic cores would agree with the shallow overturning stream function. Indeed, if we remove both midlatitude North Atlantic cores from the computation of the sum of squared residuals, we find that the shallow overturning stream function best explains the $\mathrm{Pa} / \mathrm{Th}$ data observed during GIs (Table S5).

Interstadial benthic $\delta^{13} \mathrm{C}$ values at the equator indicate the presence of (1) a northern-sourced water mass at the intermediate core site and (2) a southern-sourced water mass at the deep core site (Fig. 3b). Hence, benthic $\delta^{13} \mathrm{C}$ data support the existence of two water masses overlying each other and flowing in opposite directions as in the shallow overturning stream function. Moreover, the southern-sourced water mass likely affected core MD02-2594 on its way towards the deep equator site as reflected by its low benthic $\delta^{13} \mathrm{C}(<0.5 \%$, Negre et al., 2010).

Based on our definition of the interstadial time slices, we assume that the GI-3 time slice reflects interstadial conditions. However, because GI-3 seen in Greenland ice cores is of relatively short duration, the $\mathrm{Pa} / \mathrm{Th}$ signal of the studied sediment cores might not reflect full interstadial circulation conditions. Nonetheless, we consider it unlikely that the $\mathrm{Pa} / \mathrm{Th}$ of GI-3 reflects stadial conditions. Indeed, core MD09-3257 sedimentary Pa / Th values observed during GI3 are similar to those recorded during the GI-8 and GI-10 time slices that correspond to strict interstadials (Fig. 3). (a)

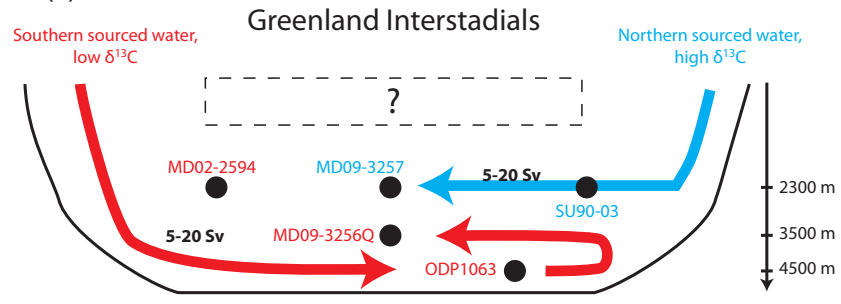

(b)

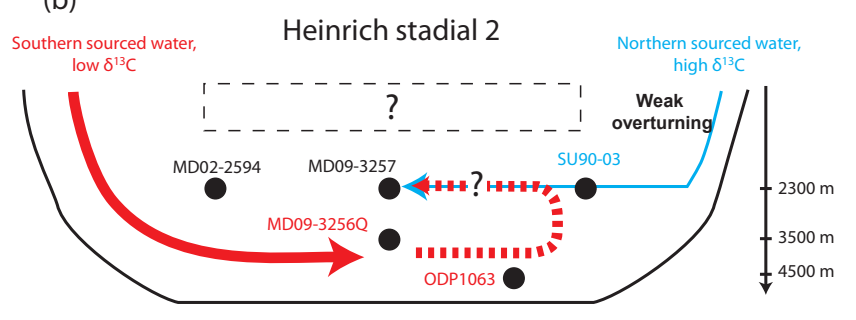

Figure 7. Sketch of the possible states of the AMOC during (a) Greenland interstadials and (b) Heinrich stadial 2. Red and blue arrows depict the southern and northern-sourced water mass, respectively. The arrows' thickness reflects the overturning rate. Core names are colored depending on which water mass influences them. In (b), cores MD09-3257 and MD02-2594 names are in black as we have no direct evidence of which water mass influences the South Atlantic Ocean during HS2. The exact position of the northwardflowing, southern-sourced water mass and its possible return flow (dashed red line) is also unknown.

There are several studies discussing a potential link between Dansgaard-Oeschger events and Atlantic circulation changes (Gottschalk et al., 2015; see Boyle, 2000 for a review), but to our knowledge, there has been no study about the geometry of the AMOC water masses during these periods. Combining the information provided by sedimentary $\mathrm{Pa} / \mathrm{Th}$ and benthic foraminiferal $\delta^{13} \mathrm{C}$ data, we reach the following conclusions concerning the Atlantic circulation below $\sim 1300 \mathrm{~m}$ during the studied GIs. A southwardflowing, northern-sourced water mass likely circulated above $\sim 2500 \mathrm{~m}$, while southern-sourced deep water circulated northwards below $\sim 4000 \mathrm{~m}$ and southwards as a return flow between $\sim 2500$ and $4000 \mathrm{~m}$ depth (Figs. 2f, 7a). Moreover, our data indicate that the geometry and state of the AMOC appear similar for GI-3, GI-8 and GI-10, despite the different ice sheet volumes characterizing the periods encompassing HS2 and HS4, respectively.

\subsubsection{Estimation of the AMOC intensity over the interstadial time slices}

Our Holocene equatorial $\mathrm{Pa} / \mathrm{Th}$ values are in reasonable agreement with previously published data from the Brazilian margin (Lippold et al., 2011) and with $\mathrm{Pa} / \mathrm{Th}$ values simulated with a 2- and 3-fold increased Holocene stream function (Fig. S7). At present, increasing the Holocene stream function is indeed necessary to improve the agreement be- 
tween simulated and measured equatorial $\mathrm{Pa} / \mathrm{Th}$ values (Lippold et al., 2011). This increase was proposed to account for the absence of west-east difference in circulation strength in the 2-D Pa / Th model, which reflects a zonally averaged circulation. Moreover, the width of the Atlantic basin is the shortest at the equator, while it is assumed constant in the model. Both these effects could cause the flow speed at the equator to be underestimated and therefore the simulated $\mathrm{Pa} / \mathrm{Th}$ ratio to be overestimated.

We performed sensitivity tests of the $\mathrm{Pa} / \mathrm{Th}$ model to varying flow rates by multiplying the shallow overturning stream function by a factor of 1,2 and 3 . Our results indicate that factors of 1 and 2 best reproduce the sedimentary $\mathrm{Pa} / \mathrm{Th}$ ratio in the Atlantic during GI time slices (Table S5).

When using the shallow overturning stream function, the flow of both the northern and southern-sourced water masses at the equator is of 5-10 Sv. As this stream function amplified by a factor of 1 and 2 best agrees with our interstadial $\mathrm{Pa} / \mathrm{Th}$ data, we assume that the water-mass flow rates provided by these shallow overturning stream functions (5-20 Sv) depict well the oceanic circulation strength during the studied interstadials. The modern flow rates of NADW (northern-sourced water mass) and AABW (southern-sourced water mass) are $\sim 27 \pm 7$ and $\sim 3 \mathrm{~Sv}$ at $4.5^{\circ} \mathrm{S}$, respectively (Lux et al., 2001). We conclude that during GI-3, GI-8 and GI-10, the flow rate of the southern-sourced deep water was likely larger than present-day AABW and that the flow rate of the northernsourced deep water may have been smaller than present-day NADW.

\subsection{Heinrich stadial 2}

\subsubsection{Comparison with the shallow overturning simulation}

$\mathrm{Pa} / \mathrm{Th}$ data from the HS2 time slice display a large vertical $\mathrm{Pa} / \mathrm{Th}$ gradient between the depths of our equatorial cores (Figs. 4a, 5a or 6a). The gradient results from the high $\mathrm{Pa} / \mathrm{Th}$ value at intermediate depth, which indicates that the core was likely overlain by sluggish waters. $\mathrm{Pa} / \mathrm{Th}$ data in the equatorial cores are therefore incompatible with the low vertical $\mathrm{Pa} / \mathrm{Th}$ gradient simulated by the shallow overturning stream function (Fig. 6, Table S4).

Moreover, the decrease in benthic $\delta^{13} \mathrm{C}$ values in both equatorial cores during HS2 is incompatible with the active northern-sourced circulation cell simulated above $2500 \mathrm{~m}$ with the shallow overturning stream function (Fig. 3, b).

Hence, both circulation and ventilation proxies indicate that there was no intense northern-sourced water flow between 1300 and $2300 \mathrm{~m}$ depth at the equator during HS2.

\subsubsection{Comparison with the Holocene simulation}

Large vertical $\mathrm{Pa} / \mathrm{Th}$ gradients are simulated in the model when a single water mass affects both equatorial cores. $\mathrm{Pa} / \mathrm{Th}$ values simulated with the Holocene stream function therefore best fit $\mathrm{Pa}$ / Th data during HS2 (Fig. 4a, Table S4). However, the very low benthic $\delta^{13} \mathrm{C}$ values measured in both equatorial cores during HSs (Fig. 3b) exclude the presence of an active northern-sourced deep-water mass in the intermediate and deep equatorial Atlantic at that time.

Hence, it is unlikely that the Holocene stream function depicts the geometry and strength of the AMOC during HS2.

\subsubsection{Comparison with the off-mode simulation}

In contrast, $\mathrm{Pa} / \mathrm{Th}$ values simulated with the off-mode stream function could reconcile the large $\mathrm{Pa} / \mathrm{Th}$ vertical gradient and the low $\delta^{13} \mathrm{C}$ of equatorial cores (Fig. 5a). In the current off-mode simulation by the iLOVECLIM model, the vertical extent of the southern-sourced water mass is not large enough to influence the equatorial core at $3500 \mathrm{~m}$ depth, resulting in an apparent low vertical $\mathrm{Pa} / \mathrm{Th}$ gradient (Fig. 2c, d). However, the model was run for a short period of time, preventing a full response of the southern-sourced deep waters to varying climatic and oceanographic conditions (Roche et al., 2014). Hence, the vertical extent of the southernsourced water mass could be larger, thereby inducing a low sedimentary $\mathrm{Pa} / \mathrm{Th}$ ratio in the deepest core of the Brazilian margin. Pa / Th data from the Bermuda Rise and South Atlantic cores are consistent with simulated $\mathrm{Pa} / \mathrm{Th}$ values from the off-mode stream function. However, the $\mathrm{Pa} / \mathrm{Th}$ data from the intermediate North Atlantic core are not in agreement with the modeled $\mathrm{Pa} / \mathrm{Th}$, as there is no deepwater formation in the high-latitude North Atlantic in the offmode stream function.

The very low benthic $\delta^{13} \mathrm{C}$ values measured in the deep equatorial core during HS2 are consistent with the simulation using the off-mode stream function, which shows a strong influence of southern-sourced water masses in the deep Atlantic. This is further supported by the increased $\varepsilon_{\mathrm{Nd}}$ in the Bermuda Rise core which indicates an increased influence of southern-sourced water masses at $4500 \mathrm{~m}$ in the North Atlantic Ocean during HS2 (Gutjahr and Lippold, 2011).

The off-mode simulation could therefore explain both $\mathrm{Pa} / \mathrm{Th}$ and $\delta^{13} \mathrm{C}$ values in the deep Atlantic and intermediate equatorial Atlantic, but neither this stream function nor the others are able to explain the $\mathrm{Pa} / \mathrm{Th}$ record of the North Atlantic core at $\sim 2500 \mathrm{~m}$ depth.

\subsubsection{Geometry and strength of the AMOC during HS2}

The low $\mathrm{Pa} / \mathrm{Th}$ and high benthic $\delta^{13} \mathrm{C}$ observed in core SU90-03 indicates that deep convection was still active in the high-latitude North Atlantic during HS2. However, the resulting water mass was probably slow enough so that its nutrient content significantly raised on its way towards the equator either through turbulent and diffusive mixing with the underlying water mass or through the degradation of ${ }^{12} \mathrm{C}$ rich organic matter sinking from surface waters. This would explain the low $\delta^{13} \mathrm{C}$ values measured in the intermediate 
equatorial core. Similarly, a long transit time of the water mass from the North Atlantic deep convection sites to the Brazilian margin could explain the high $\mathrm{Pa} / \mathrm{Th}$ values measured in the intermediate equatorial core, as dissolved $\mathrm{Pa}$ was allowed sufficient time to equilibrate through reversible exchange with particulate matter. This progressive equilibration could have led to the sedimentary $\mathrm{Pa} / \mathrm{Th}$ latitudinal gradient observed at $\sim 2500 \mathrm{~m}$ depth, from low sedimentary $\mathrm{Pa} / \mathrm{Th}$ values in the midlatitude North Atlantic (SU90-03) to high values in the equatorial Atlantic (MD09-3257; Fig. 5a).

Considering that both $\mathrm{Pa} / \mathrm{Th}$ and benthic $\delta^{13} \mathrm{C}$ values suggest an increased influence of southern-sourced waters at the equatorial and Bermuda Rise deep sites, the off-mode stream function best depicts the geometry of the AMOC during HS2 below $2500 \mathrm{~m}$, i.e., southern-sourced deep waters likely filled the deep Atlantic Ocean (Fig. 7b). The influence of the southern-sourced water mass likely extended vertically above $3500 \mathrm{~m}$ depth, probably at least up to $2500 \mathrm{~m}$ depth, as indicated by the low $\mathrm{Pa} / \mathrm{Th}$ value of the deep equatorial core. However, given the discrepancy between the offmode simulation and observed $\mathrm{Pa} / \mathrm{Th}$ values in the North Atlantic intermediate core, it is difficult to assess the exact latitudinal and vertical extent of the southern-sourced waters. Above $2500 \mathrm{~m}$, a weak water flow originating from northern deep convection sites probably influenced the Atlantic, perhaps down to equatorial latitudes (Fig. 7b).

The geometry of the Atlantic deep water masses inferred from our sedimentary $\mathrm{Pa} / \mathrm{Th}$ and benthic $\delta^{13} \mathrm{C}$ records during HS2 is consistent with previous modeling experiments (e.g., Ganopolski and Rahmstorf, 2001) and with water mass ventilation (Elliot et al., 2002; Vidal et al., 1997; Zahn et al., 1997) and circulation intensity (Gherardi et al., 2005; McManus et al., 2004) proxies indicating that deep water circulation slowed down during Heinrich stadials. Furthermore, our data indicate that a northern-sourced water mass was active above $2500 \mathrm{~m}$ during HS2, as inferred for HS1 (Gherardi et al., 2009; Roche et al., 2014) and HS2 (Lynch-Stieglitz et al., 2014; Wary et al., 2015) in previous studies. However, quantifying the intensity of the AMOC upper circulation cell during this period remains difficult since there is at present no numerical simulation in reasonably good agreement with both the circulation and ventilation proxies measured in the Atlantic.

\section{Conclusions}

We have shown that both the geometry and strength of the AMOC during three interstadials of the last glacial period (i.e., the GI-3, GI-8 and GI-10 intervals) was markedly different from those of the modern AMOC. Our data suggest that a northern-sourced water mass circulated above $2500 \mathrm{~m}$ depth with a flow rate ranging between 5 and $20 \mathrm{~Sv}$, which is lower than the intensity of present-day NADW. Below $4000 \mathrm{~m}$, a southern-sourced deep water mass likely flowed northward with an intensity of 5-20 Sv, which is larger than the modern AABW flow rate. Between 2500 and $4000 \mathrm{~m}$ depth, the southern-sourced deep water likely circulated southwards as a return flow.

Our data also show that the geometry of the AMOC likely changed at the onset of HS2 and that the deep Atlantic below $2500 \mathrm{~m}$ was then probably dominated by a single southernsourced water mass that can be traced up to $35^{\circ} \mathrm{N}$ at $4500 \mathrm{~m}$. This water mass probably affected the equatorial Atlantic between 2500 and $3500 \mathrm{~m}$ depth. A slow, southward-flowing water likely circulated between 1500 and $2500 \mathrm{~m}$ in the North Atlantic, but its presence at the equator remains difficult to assess.

\section{Data availability}

Data related to this article are available as a supplement file and on PANGAEA (doi:10.1594/PANGAEA.865401).

\section{The Supplement related to this article is available online at doi:10.5194/cp-12-2061-2016-supplement.}

Author contributions. Pierre Burckel, Claire Waelbroeck, Sylvain Pichat, Jeanne Gherardi and Jörg Lippold designed the research; Pierre Burckel, Samuel L. Jaccard and François Thil performed the sedimentary $\mathrm{Pa}$ / Th measurements; Samuel L. Jaccard and Jörg Lippold performed the opal measurements; Aline Govin performed the XRF measurements; Yiming Luo generated the simulated $\mathrm{Pa} / \mathrm{Th}$ data; and Didier M. Roche generated the stream functions. Pierre Burckel and Claire Waelbroeck wrote the manuscript.

Acknowledgements. $\mathrm{Pa} / \mathrm{Th}$ measurements were funded by the CNRS/INSU LEFE project ACCENT. This work is a contribution to the RETRO project, a joint European Science Foundation (ESF)/EUROMARC, funded by Research Council of Norway (RCN), France (CNRS/INSU), Germany and the Netherlands, and to the ACCLIMATE ERC project. The research leading to these results has received funding from the European Research Council under the European Union's Seventh Framework Programme (FP7/2007-2013)/ERC grant agreement no. 339108. Samuel L. Jaccard was funded by the Swiss National Foundation (grants PBEZ2-111588 and PP00P2_144811). Cores MD09-3256Q and MD09-3257 were collected on board R/V Marion Dufresne during RETRO Cruise III, supported by ESF EUROMARC project RETRO, IPEV and ANR project ANR-09-BLAN-0347. We thank the IPEV team, crew members of R/V Marion Dufresne and all scientists who participated in RETRO Cruise III. We are thankful to M. Roy-Barman for expert advice on $\mathrm{Pa} / \mathrm{Th}$ measurements on LSCE MC-ICP-MS. We acknowledge C. Moreau, J.-P. Dumoulin and the UMS ARTEMIS for AMS ${ }^{14} \mathrm{C}$ dates, and $\mathrm{G}$. Isguder, L. Mauclair and F. Dewilde for invaluable technical assistance. We are thankful to Roger Francois and one anonymous reviewer 
for their constructive comments which helped to clarify this manuscript. This is LSCE contribution 5757.

Edited by: L. Beaufort

Reviewed by: R. Francois and one anonymous referee

\section{References}

Anderson, R. F., Fleisher, M. Q., and Lao, Y.: Glacial-interglacial variability in the delivery of dust to the central equatorial Pacific Ocean, Earth Planet. Sc. Lett., 242, 406-414, doi:10.1016/j.epsl.2005.11.061, 2006.

Böhm, E., Lippold, J., Gutjahr, M., Frank, M., Blaser, P., Antz, B., Fohlmeister, J., Frank, N., Andersen, M. B., and Deininger, M.: Strong and deep Atlantic meridional overturning circulation during the last glacial cycle, Nature, 517, 73-76, doi:10.1038/nature14059, 2015.

Bourillet, J.-F., Damy, G., Dussud, L., Sultan, N., Woerther, P., and Migeon, S.: Behaviour Of A Piston Corer From Accelerometers And New Insights On Quality Of The Recovery., Proc. 6th Int. Off shore Site Investig, Geotech. Conf., Confronting New Challenges Shar, Knowledge, 11-13 Sept. 2007, London, UK, available at: http://archimer.ifremer.fr/doc/00071/18198/ (last access: 3 November 2016), 2007.

Boyle, E. A.: Is ocean thermohaline circulation linked to abrupt stadial/interstadial transitions?, Quaternary Sci. Rev., 19, 255-272, doi:10.1016/S0277-3791(99)00065-7, 2000.

Bradtmiller, L. I., McManus, J. F., and Robinson, L. F.: 231Pa / 230Th evidence for a weakened but persistent Atlantic meridional overturning circulation during Heinrich Stadial 1, Nat. Commun., 5, 5817, doi:10.1038/ncomms6817, 2014.

Broecker, W. S., Peteet, D. M., and Rind, D.: Does the oceanatmosphere system have more than one stable mode of operation?, Nature, 315, 21-26, doi:10.1038/315021a0, 1985.

Burckel, P., Waelbroeck, C., Gherardi, J. M., Pichat, S., Arz, H., Lippold, J., Dokken, T., and Thil, F.: Atlantic Ocean circulation changes preceded millennial tropical South America rainfall events during the last glacial, Geophys. Res. Lett., 42, 411-418, doi:10.1002/2014GL062512, 2015.

Burckel, P., Waelbroeck, C., Luo, Y., Roche, D. M., Pichat, S., Jaccard, S. L., Gherardi, J.-M., Govin, A., Lippold, J., and Thil, F.: The Atlantic Meridional Overturning Circulation during the last glacial, Dataset \#865401, doi:10.1594/PANGAEA.865401, 2016.

Chapman, M. R., Shackleton, N. J., and Duplessy, J.-C.: Sea surface temperature variability during the last glacial-interglacial cycle: assessing the magnitude and pattern of climate change in the North Atlantic, Palaeogeogr. Palaeocl., 157, 1-25, doi:10.1016/S0031-0182(99)00168-6, 2000.

Chase, Z., Anderson, R. F., Fleisher, M. Q., and Kubik, P. W.: The influence of particle composition and particle flux on scavenging of Th, Pa and Be in the ocean, Earth Planet. Sc. Lett., 204, 215229, doi:10.1016/S0012-821X(02)00984-6, 2002.

Choi, M. S., Francois, R., Sims, K., Bacon, M. P., Brown-Leger, S., Fleer, a P., Ball, L., Schneider, D., and Pichat, S.: Rapid determination of ${ }^{230} \mathrm{Th}$ and ${ }^{231} \mathrm{~Pa}$ in seawater by desolvated micronebulization Inductively Coupled Plasma magnetic sector mass spectrometry, Mar. Chem., 76, 99-112, 2001.
Christl, M., Lippold, J., Hofmann, A., Wacker, L., Lahaye, Y., and Synal, H. A.: 231Pa / 230Th: A proxy for upwelling off the coast of West Africa, Nucl. Instrum. Meth. B, 268, 1159-1162, doi:10.1016/j.nimb.2009.10.123, 2010.

Coplen, T. B.: Normalization of oxygen and hydrogen isotope data, Chem. Geol. Isot. Geosci. Sect., 72, 293-297, doi:10.1016/01689622(88)90042-5, 1988.

Curry, W. B. and Oppo, D. W.: Glacial water mass geometry and the distribution of delta $13 \mathrm{C}$ of Sigma $\mathrm{CO}_{2}$ in the western Atlantic Ocean, Paleoceanography, 20, 1-12, doi:10.1029/2004PA001021, 2005.

Curry, W. B., Duplessy, J. C., Labeyrie, L. D., and Shackleton, N. J.: Changes in the distribution of $\delta 13 \mathrm{C}$ of deep water $\Sigma \mathrm{CO} 2$ between the Last Glaciation and the Holocene, Paleoceanography, 3, 317-341, doi:10.1029/PA003i003p00317, 1988.

Duplessy, J. C., Shackleton, N. J., Fairbanks, R. G., Labeyrie, L., Oppo, D., and Kallel, N.: Deepwater source variations during the last climatic cycle and their impact on the global deepwater circulation, Paleoceanography, 3, 343-360, doi:10.1029/PA003i003p00343, 1988.

Duplessy, J.-C., Shackleton, N. J., Matthews, R. K., Prell, W., Ruddiman, W. F., Caralp, M., and Hendy, C. H.: 13C Record of benthic foraminifera in the last interglacial ocean: Implications for the carbon cycle and the global deep water circulation, Quaternary Res., 21, 225-243, doi:10.1016/0033-5894(84)90099-1, 1984.

Elliot, M., Labeyrie, L., and Duplessy, J. C.: Changes in North Atlantic deep-water formation associated with the Dansgaard - Oeschger temperature oscillations (60-10 ka), Quaternaary Sci. Rev., 21, 1153-1165, doi:10.1016/S0277-3791(01)00137-8, 2002.

Francois, R.: Paleoflux and Paleocirculation from Sediment 230Th and ${ }^{231} \mathrm{~Pa} /{ }^{230} \mathrm{Th}$, in Proxies in Late Cenozoic Paleoceanography, Elsevier, 1, 681-716, 2007.

Ganopolski, A. and Rahmstorf, S.: Rapid changes of glacial climate simulated in a coupled climate model, Nature, 409, 153158, doi:10.1038/35051500, 2001.

Gherardi, J. M., Labeyrie, L., McManus, J. F., Francois, R., Skinner, L. C., and Cortijo, E.: Evidence from the Northeastern Atlantic basin for variability in the rate of the meridional overturning circulation through the last deglaciation, Earth Planet. Sc. Lett., 240, 710-723, doi:10.1016/j.epsl.2005.09.061, 2005.

Gherardi, J.-M., Labeyrie, L., Nave, S., Francois, R., McManus, J. F., and Cortijo, E.: Glacial-interglacial circulation changes inferred from ${ }^{231} \mathrm{~Pa} /{ }^{230} \mathrm{Th}$ sedimentary record in the North Atlantic region, Paleoceanography, 24, 1-14, doi:10.1029/2008PA001696, 2009.

Gottschalk, J., Skinner, L. C., Misra, S., Waelbroeck, C., Menviel, L., and Timmermann, A.: Abrupt changes in the southern extent of North Atlantic Deep Water during Dansgaard-Oeschger events, Nat. Geosci, 8, 950-954, doi:10.1038/ngeo2558, 2015.

Guihou, A., Pichat, S., Nave, S., Govin, A., Labeyrie, L., Michel, E., and Waelbroeck, C.: Late slowdown of the Atlantic Meridional Overturning Circulation during the Last Glacial Inception: New constraints from sedimentary (231Pa / 230Th), Earth Planet. Sc. Lett., 289, 520-529, doi:10.1016/j.epsl.2009.11.045, 2010.

Guihou, A., Pichat, S., Govin, A., Nave, S., Michel, E., Duplessy, J. C., Telouk, P., and Labeyrie, L.: Enhanced Atlantic Meridional Overturning Circulation supports the Last 
Glacial Inception, Quaternary Sci. Rev., 30, 1576-1582, doi:10.1016/j.quascirev.2011.03.017, 2011.

Gutjahr, M. and Lippold, J.: Early arrival of Southern Source Water in the deep North Atlantic prior to Heinrich event 2, Paleoceanography, 26, 1-9, doi:10.1029/2011PA002114, 2011.

Hall, I. R., Moran, S. B., Zahn, R., Knutz, P. C., Shen, C. C., and Edwards, R. L.: Accelerated drawdown of meridional overturning in the late-glacial Atlantic triggered by transient pre$\mathrm{H}$ event freshwater perturbation, Geophys. Res. Lett., 33, 1-5, doi:10.1029/2006GL026239, 2006.

Heinrich, H.: Origin and consequences of cyclic ice rafting in the Northeast Atlantic Ocean during the past 130,000 years, Quaternary Res., 29, 142-152, doi:10.1016/0033-5894(88)90057-9, 1988.

Jaeschke, A., Rühlemann, C., Arz, H., Heil, G., and Lohmann, G.: Coupling of millennial-scale changes in sea surface temperature and precipitation off northeastern Brazil with high-latitude climate shifts during the last glacial period, Paleoceanography, 22, 1-10, doi:10.1029/2006PA001391, 2007.

Johnsen, S. J., Clausen, H. B., Dansgaard, W., Fuhrer, K., Gundestrup, N., Hammer, C. U., Iversen, P., Jouzel, J., Stauffer, B., and Steffensen, J. P.: Irregular glacial interstadials recorded in a new Greenland ice core, Nature, 359, 311-313, doi:10.1038/359311a0, 1992.

Jonkers, L., Zahn, R., Thomas, A., Henderson, G., Abouchami, W., Francois, R., Masque, P., Hall, I. R., and Bickert, T.: Deep circulation changes in the central South Atlantic during the past 145 kyrs reflected in a combined Pa-231 / Th-230, Neodymium isotope and benthic delta C-13 record, Earth Planet. Sc. Lett., 419, 14-21, doi:10.1016/j.eps1.2015.03.004, 2015.

Kindler, P., Guillevic, M., Baumgartner, M., Schwander, J., Landais, A., and Leuenberger, M.: Temperature reconstruction from 10 to 120 kyr b2k from the NGRIP ice core, Clim. Past, 10, 887-902, doi:10.5194/cp-10-887-2014, 2014.

Lambeck, K. and Chappell, J.: Sea level change through the last glacial cycle, Science, 292, 679-686, doi:10.1126/science.1059549, 2001.

Lippold, J., Gherardi, J. M., and Luo, Y.: Testing the 231Pa/230Th paleocirculation proxy: A data versus 2-D model comparison, Geophys. Res. Lett., 38, 1-7, doi:10.1029/2011GL049282, 2011.

Lippold, J., Luo, Y., Francois, R., Allen, S. E., Gherardi, J., Pichat, S., Hickey, B., and Schulz, H.: Strength and geometry of the glacial Atlantic Meridional Overturning Circulation, Nat. Geosci., 5, 813-816, doi:10.1038/ngeo1608, 2012.

Luo, Y., Francois, R., and Allen, S. E.: Sediment ${ }^{231} \mathrm{~Pa} /{ }^{230} \mathrm{Th}$ as a recorder of the rate of the Atlantic meridional overturning circulation: insights from a 2-D model, Ocean Sci., 6, 381-400, doi:10.5194/os-6-381-2010, 2010.

Lux, M., Mercier, H., and Arhan, M.: Interhemispheric exchanges of mass and heat in the Atlantic Ocean in January-March 1993, Deep-Sea Res. Pt. I, 48, 605-638, doi:10.1016/S09670637(00)00033-9, 2001.

Lynch-Stieglitz, J., Stocker, T. F., Broecker, W. S., and Fairbanks, R. G.: The influence of air-sea exchange on the isotopic composition of oceanic carbon: Observations and modeling, Global Biogeochem. Cy., 9, 653-665, doi:10.1029/95GB02574, 1995.

Lynch-Stieglitz, J., Schmidt, M. W., Gene Henry, L., Curry, W. B., Skinner, L. C., Mulitza, S., Zhang, R., and Chang, P.: Muted change in Atlantic overturning circulation over some glacial-aged Heinrich events, Nat. Geosci., 7, 1-7, doi:10.1038/ngeo2045, 2014.

McManus, J. F., Francois, R., Gherardi, J.-M., Keigwin, L. D., and Brown-Leger, S.: Collapse and rapid resumption of Atlantic meridional circulation linked to deglacial climate changes, Nature, 428, 834-837, doi:10.1038/nature02494, 2004.

Negre, C., Zahn, R., Thomas, A. L., Masqué, P., Henderson, G. M., Martínez-Méndez, G., Hall, I. R., and Mas, J. L.: Reversed flow of Atlantic deep water during the Last Glacial Maximum, Nature, 468, 84-88, doi:10.1038/nature09508, 2010.

Rasmussen, S. O., Bigler, M., Blockley, S. P., Blunier, T., Buchardt, S. L., Clausen, H. B., Cvijanovic, I., Dahl-Jensen, D., Johnsen, S. J., Fischer, H., Gkinis, V., Guillevic, M., Hoek, W. Z., Lowe, J. J., Pedro, J. B., Popp, T., Seierstad, I. K., Steffensen, J. P., Svensson, A. M., Vallelonga, P., Vinther, B. M., Walker, M. J. C., Wheatley, J. J., and Winstrup, M.: A stratigraphic framework for abrupt climatic changes during the Last Glacial period based on three synchronized Greenland ice-core records: refining and extending the INTIMATE event stratigraphy, Quaternary Sci. Rev., 106, 14-28, doi:10.1016/j.quascirev.2014.09.007, 2014.

Reimer, P. J., Bard, E., Bayliss, A., Beck, J. W., Blackwell, P. G., Ramsey, C. B., Buck, C. E., Cheng, H., Edwards, R. L., Friedrich, M., Grootes, P. M., Guilderson, T. P., Haflidason, H., Hajdas, I., Hatte, C., Heaton, T. J., Hoffmann, D. L., Hogg, A. G., Hughen, K. A., Kaiser, K. F., Kromer, B., Manning, S. W., Niu, M., Reimer, R. W., Richards, D. A., Scott, E. M., Southon, J. R., Staff, R. A., Turney, C. S. M., and van der Plicht, J.: IntCal13 and Marine13 Radiocarbon Age Calibration Curves 0-50 000 years Cal BP, Radiocarbon, 55, 1869-1887, 2013.

Rhein, M., Stramma, L., and Send, U.: The Atlantic Deep Western Boundary Current?, Water masses and transports near the equator, 100, 2441-2457, 1995.

Roche, D. M., Dokken, T. M., Goosse, H., Renssen, H., and Weber, S. L.: Climate of the Last Glacial Maximum: sensitivity studies and model-data comparison with the LOVECLIM coupled model, Clim. Past, 3, 205-224, doi:10.5194/cp-3-205-2007, 2007.

Roche, D. M., Wiersma, A. P., and Renssen, H.: A systematic study of the impact of freshwater pulses with respect to different geographical locations., Clim. Dynam., 34, 997-1013, 2010.

Roche, D. M., Paillard, D., Caley, T., and Waelbroeck, C.: LGM hosing approach to Heinrich Event 1: results and perspectives from data-model integration using water isotopes, Quaternary Sci. Rev., 106, 247-261, doi:10.1016/j.quascirev.2014.07.020, 2014.

Rohling, E. and Cooke, S.: Stable oxygen and carbon isotopes in foraminiferal carbonate shells, Mod. foraminifera, 239-258, available at: http://www.springerlink.com/index/ R519428618723716.pdf (last access: 3 November 2016), 2003.

Schlitzer, R.: Electronic Atlas of WOCE Hydrographic and Tracer Data Now Available, Eos Trans. AGU, 81, 45, 2000.

Schlitzer, R.: Ocean Data View, http://odv.awi.de (last access: 3 November 2016), 2015.

Schott, F. A.: The zonal currents and transports at $35^{\circ} \mathrm{W}$ in the tropical Atlantic, Geophys. Res. Lett., 30, 35-38, doi:10.1029/2002GL016849, 2003.

Skinner, L. C. and McCave, I. N.: Analysis and modelling of gravity- and piston coring based on soil mechanics, Mar. Geol., 199, 181-204, doi:10.1016/S0025-3227(03)00127-0, 2003. 
Skinner, L. C., Shackleton, N. J., and Elderfield, H.: Millennialscale variability of deep-water temperature and $\delta 180 \mathrm{dw}$ indicating deep-water source variations in the Northeast Atlantic, 0-34 cal.ka BP, Geochem. Geophy. Geosy., 4, 12, doi:10.1029/2003GC000585, 2003.

Talley, L. D., Reid, J. L., and Robbins, P. E.: Data-based meridional overturning streamfunctions for the global ocean, J. Climate, 16, 3213-3226, 2003.

Thomas, A. L., Henderson, G. M., and Robinson, L. F.: Interpretation of the $231 \mathrm{~Pa} / 230 \mathrm{Th}$ paleocirculation proxy: New watercolumn measurements from the southwest Indian Ocean, Earth Planet. Sc. Lett., 241, 493-504, doi:10.1016/j.epsl.2005.11.031, 2006.

Vidal, L., Labeyrie, L., Cortijo, E., Arnold, M., Duplessy, J.-C., Michel, E., Becqué, S., and van Weering, T. C. E.: Evidence for changes in the North Atlantic Deep Water linked to meltwater surges during the Heinrich events, Earth Planet. Sc. Lett., 146, 13-27, doi:10.1016/S0012-821X(96)00192-6, 1997.

Wary, M., Eynaud, F., Sabine, M., Zaragosi, S., Rossignol, L., Malaizé, B., Palis, E., Zumaque, J., Caulle, C., Penaud, A., Michel, E., and Charlier, K.: Stratification of surface waters during the last glacial millennial climatic events: a key factor in subsurface and deep-water mass dynamics, Clim. Past, 11, 15071525, doi:10.5194/cp-11-1507-2015, 2015.
Woerther, P. and Bourillet, J. F.: Exploitation des mesures faites avec les accéléromètres sur le carottier CAPYPSO -Mission SEDICAR4-ALIENOR, Ifremer, Brest, pp. 47 \& 4 Annexes, 2005.

Yu, E.-F., Francois, R., and Bacon, M. P.: Similar rates of modern and last-glacial ocean thermohaline circulation inferred from radiochemical data, Nature, 379, 689-694, doi:10.1038/379689a0, 1996.

Zahn, R., Winn, K., and Sarnthein, M.: Benthic foraminiferal $\delta 13 \mathrm{C}$ and accumulation rates of organic carbon: Uvigerina Peregrina group and Cibicidoides Wuellerstorfi, Paleoceanography, 1, 27 42, doi:10.1029/PA001i001p00027, 1986.

Zahn, R., Schönfeld, J., Kudrass, H.-R., Park, M.-H., Erlenkeuser, H., and Grootes, P.: Thermohaline instability in the North Atlantic during meltwater events: Stable isotope and ice-rafted detritus records from Core SO75-26KL, Portuguese Margin, Paleoceanography, 12, 696-710, doi:10.1029/97PA00581, 1997. 